\title{
Factor Analysis of Student's Satisfaction on Brand Image and Positioning of Adventist Higher Education Institution in Southern Asia Pacific Division
}

\author{
Francis Hutabarat \\ Faculty of Business Administration \\ Universitas Advent Indonesia \\ Bandung, Indonesia \\ Franklin Hutabarat \\ Faculty of Religious Studies \\ Asia-Pacific International University \\ MuakLek, Thailand
}

\begin{abstract}
This research aims to distinguish the factor of brand image and position affecting student satisfaction in the Southern Asia Pacific Division Adventist Higher Education Institutions. Knowing these factors could help leaders in educational institutions to thoroughly plan their strategies and further inquiry on student satisfaction. A set of the instrument of the questionnaire was acquired and distributed to students respondent at three higher education institution institutions in the Southern Asia Pacific Division Higher Education Institution namely Asia Pacific International University of Thailand, Adventist University of the Philippines of the Philippines and Universitas Advent Indonesia of Indonesia. Exploratory factor analysis was used to distinguish the underlying dimensions that drive student satisfaction. Factor analysis pertaining to analysis on dimensions of Academic Courses. The results show that the KMO test is valued at 0.919 which is > 0.5; hence, the sample size is adequate for the analysis. On the other hand, the commonalities of all the variables are surpassing .4; consequently, all the variables are valuable in the model. The results show that factors in the analysis of student satisfaction on brand image and brand positioning at AIU,AUP and UNAI are that the courses helped them in: known nationally, maximum service, good reputation, provide health insurance, convenience registration process, provide scientific education \& spiritual education, spiritual need.
\end{abstract}

Keyword: Satisfaction, Factor Analysis, Higher Education Institution

\section{Introduction}

In the past two decades, The Adventist higher education sector that has changed politically, socially, economically, and globally, and the market has grown to be more successful globally, recommend that the administration for the institution applies a strategy focused on the business to maintain competitive advantage. When designing and implementing a market-oriented approach, managing and understanding student satisfaction and service quality requirements is essential for the management of the university. In the development of society, higher education institutions are significant. Since the institution is essentially a manufacturer of educated and well grounded individuals, the same institution is one of the critical pillars of a country's growth. Similarly, higher education institutions ought to take the happiness of their learners seriously. In this context, as we know, young people have been striving to reach their purpose and dream in life in their academic life. Their ambition was in line with their talent and experience in their chosen field. Here, we can see that it is critical for the institution to build and promote factors for student satisfaction in particular. These young people have made every effort to achieve their aim and happiness. In addition, disappointment will lead to many things, at a certain stage, for the students it means their lives ahead, how the decision-making will be, whether they will have frustration and whether they will have broken character because in the course of their academic life they are not happy. On the other hand, we see that society looks at the institution's growth and may provide a different outlook that goes unfavourably for the university.Customer satisfaction has been placed at the core of the literature related to marketing (Ford, Joseph, and Joseph 1999). Techniques were researched and developed by academics and practitioners for maintaining profitable customer relationships, since satisfied customers typically contribute to customer satisfaction and the loyalty of customer(Parasuraman, Berry, and Zeithaml 1991). For example, (Direkvand-Moghadam et al. 2014)see the effectiveness of patient satisfaction in the emergency care unit in any service institution, while(Yusoff, McLeay, and Woodruffe-Burton 2015)sees the dimension in a higher education institution that drives business students.

In addition, customer satisfaction is part of their decision-making and the identification of customer decisionmaking goes back to an early economist, Bernoulli, von Neumann, and Morgenstern, some 300 years ago, in which the basis for consumer decision-making began to be established and pointed out. In terms of student satisfaction, previous studies by (Shirazi 2017), (Parahoo, Harvey, and Tamim 2013), (Tahar et al. 2013), and (Khosravi et al. 
2013) look at the satisfaction of the student and the factors that influence it. To this end, one can see that happiness in one's life is important. On this basis, according to research findings by (DeShields, Kara, and Kaynak 2005) and (Helgesen and Nesset 2007), they propose that continued student satisfaction research would assist them in their academic achievement and in addition, the preservation and life of the institution of higher education. Higher education institutions should also aim for a desired picture that will help draw more young people and provide them with service and academic satisfaction in pursuing education, they say.

\section{Theoretical Foundation}

In their opinions on standards for satisfaction assessment, literature varies. In terms of fulfilment, a student looks at her educational experiences, according to(Kuo et al. 2014). Students with fulfilling interactions will also continue their studies, according to analysis. According to (Chua 2004), on the other hand, satisfaction is a crucial factor in the continuity and development of an organization in the midst of rivalry. In addition,(Athanassopoulos, Gounaris, and Stathakopoulos 2001) see that satisfactory students are also predictably loyal students, contributing to their decision to seek a higher degree at the same university. In his study, (Shirazi 2017) gives three main indicators of academic satisfaction, namely: experienced workers, reciprocal respect between teachers and students, and the induction of self-esteem among students by faculty and authorities.(James 2002) and (Umbach and Porter 2002)studies that showed that students with higher education satisfaction are discovered in students who do study and communicate with their professor.

\section{Methodology}

At three Adventist higher education institutions in the Southern Asia Pacific Division Higher Education College, namely Asia Pacific International University, Adventist University of the Philippines and Universitas Advent Indonesia, a questionnaire as a study tool was created and distributed to student respondents. There are about 3,000 students studying at both institutions of higher education. There are 99 samples used for the studies based on the sample given and the findings were checked and cleared as a general respondent to the students using KMO and Bartlett's test. The method of factor analysis related to the analysis of brand image measurements and brand positioning was used. The following important findings of the study are as follows: The characteristics of the variables used in the study are investigated by descriptive statistics (Priyatno 2014). (Verma 2013) reported that the test of KMO and Bartlett is used for factor analysis to see if the data is satisfactory for the sample, as well as populations of all variables, scree map, total variance explained, and component matrix: rotated component matrix and unrotated factor solution, as well as varimax-rotated solution. According to (Verma 2013), the study can produce test battery in applying factor analysis, showing the number of factors to be maintained and the overall variance explained by these factors; the study will distinguish (analyze) the variables (values) in each (all) factor retained within the final solution on the basis of its measured loadings; the study will provide names for each retain factor

\section{Results and Discussion}

The results of the analysis provided solutions to various study-related concerns. The study used statistical tools to process relevant outputs explicitly selected for the study discussion. The different approach will assess the test battery to evaluate student brand image and role satisfaction by using the statistical method of factor analysis.

\section{Descriptive Statistic}

The study uses mean of likert scale of 1 to 10 and Standard Deviation (SD) to classify the variables defined in the analysis. Table 1 look on the characteristic of variables in the study using the mean and SD for all variables in the study. The findings indicate that from the questions given, the respondent shows that they are agree and strongly agree that they are satisfied with Academic Courses given in the university.

\section{Profile per university}

Table 2 shows the mean result per university that resulted in Asia-Pacific International University respondent has the highest satisfaction result with 79.9\% satisfaction, followed by Universitas Advent Indonesia by 74.69\%. Adventist University of the Philippines has the lowest result of satisfaction with $69.95 \%$ satisfaction result. 
Table 1. Descriptive Statistic

\begin{tabular}{|c|c|c|c|c|}
\hline No & Variables & Mean & Std. Deviation & $\begin{array}{l}\text { Analysis } \\
\mathbf{N}\end{array}$ \\
\hline 1 & University has good reputation in terms of direct graduates to work & 7.6162 & 1.39757 & 99 \\
\hline 2 & University has maximum service & 7.0808 & 1.52982 & 99 \\
\hline 3 & University is known nationally & 6.4343 & 1.98032 & 99 \\
\hline 4 & University provides scientific education and spiritual education & 8.8182 & 1.17251 & 99 \\
\hline 5 & The quality of education is in accordance with government standards & 8.0606 & 1.49023 & 99 \\
\hline 6 & University provides convenience from the registration process to college & 7.1515 & 2.13027 & 99 \\
\hline 7 & University provides health insurance for students who study & 7.8788 & 1.84763 & 99 \\
\hline 8 & I feel proud studying at the university & 8.1414 & 1.74969 & 99 \\
\hline 9 & Universitygives a classy impression when studying & 7.4242 & 1.85764 & 99 \\
\hline 10 & I feel happy to gain knowledge while studying at university & 8.1515 & 1.68646 & 99 \\
\hline 11 & I chose this university because of my spiritual need & 7.8889 & 1.92666 & 99 \\
\hline 12 & I collected information before studying at the university & 6.8384 & 2.55434 & 99 \\
\hline 13 & $\begin{array}{l}\text { I chose the university because the quality of service matched my } \\
\text { expectations }\end{array}$ & 6.8485 & 2.10618 & 99 \\
\hline 14 & I am happy to share university information with friends and family & 7.8788 & 1.96018 & 99 \\
\hline 15 & I invite friends and family to study at the university & 7.4747 & 2.27831 & 99 \\
\hline
\end{tabular}

Table 2. Profile per university

\begin{tabular}{llll}
\hline No & Variables & Mean & Analysis N \\
\hline 1 & Universitas Advent Indonesia & 7.469444 & 48 \\
2 & Asia-Pacific International University & 7.996190 & 35 \\
3 & Adventist University of the Philippines & 6.995833 & 16 \\
\hline
\end{tabular}

\section{KMO \& Bartlett's Test}

Table 3 displays KMO test result, which expresses whether data size for the study in terms of factor analysis was adequate or not. Based on table 3, the value is 0.919 and it is > 0.5; therefore, the data has adequate size or the analysis. Further, Bartlett test of sphericity is used to test the null hypothesis that the correlation matrix is an identity matrix (Verma, 2013). Since significant value (p-value) of correlation matrix is 0.000 which is $<0.01$ hence it is significant, and the correlation matrix is not an identity matrix. Therefore, the factor model is appropriate.

Table 3. KMO and Bartlett's Test

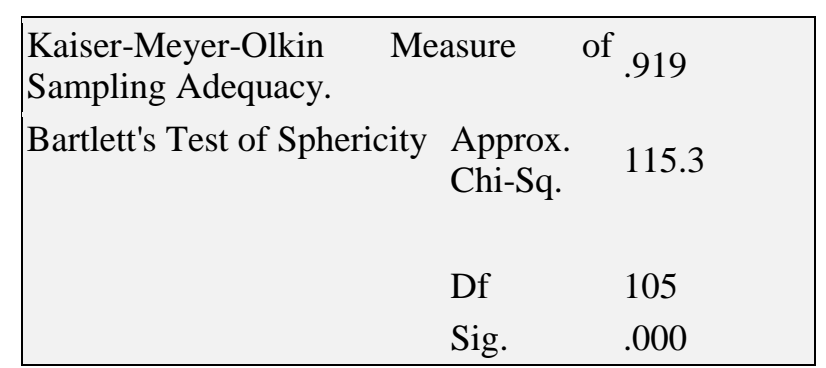

\section{Communalities Test}

In this statistic analysis, higher communality of a variable point to that the main portion of its variability is explained by the identified factors in the analysis. Stipulation for communality of variable is < .4 (Verma, 2013). Communalities table, variable $\mathrm{X} 1$ is 0.605 . This means that about $60.5 \%$ of the variance of the comfort variable can be explained by the formed factors. Likewise for the other variables. Result from table 4 indicate that the communalities of all the variables are more than .4 ; therefore, all the variables are useful for the model. 
Table 4Communalities Test

\begin{tabular}{lll}
\hline \multicolumn{1}{c}{ Variables } & Initial & Extraction \\
\hline University has good reputation in terms of direct graduates to work & 1.000 & .605 \\
University has maximum service & 1.000 & .790 \\
University is known nationally & 1.000 & .765 \\
University provides scientific education and spiritual education & 1.000 & .676 \\
The quality of education is in accordance with government standards & 1.000 & .666 \\
University provides convenience from the registration process to college & 1.000 & .817 \\
University provides health insurance for students who study & 1.000 & .766 \\
I feel proud studying at the university & 1.000 & .719 \\
University gives a classy impression when studying & 1.000 & .801 \\
I feel happy to gain knowledge while studying at university & 1.000 & .840 \\
I chose this university because of my spiritual need & 1.000 & .622 \\
I collected information before studying at the university & 1.000 & .603 \\
I chose the university because the quality of service matched my expectations & 1.000 & .718 \\
I am happy to share university information with friends and family & 1.000 & .795 \\
I invite friends and family to study at the university & 1.000 & .670
\end{tabular}

\section{Eigen value}

After rotation, it can be seen that the first, the second and the third factors explain 24.844, 24.104 and $23.410 \%$ of the total variance, respectively. Hence, these factors together can explain $72.358 \%$ of total variance in the study. The values of factors in the table displays that factor retained in the study are only for those factors with Eigen values 1 or more than 1(Verma 2013). Here, it can be seen that the Eigen value for the first three factors are >1; consequently, only three factors have been retained in this study.

Table 5. Total Variance Explained

\begin{tabular}{|c|c|c|c|c|c|c|c|c|c|}
\hline \multirow[b]{2}{*}{$\begin{array}{l}\text { Comp } \\
\text { onent }\end{array}$} & \multicolumn{3}{|c|}{ Initial Eigenvalues } & \multicolumn{3}{|c|}{$\begin{array}{l}\text { Extraction } \\
\text { Loadings }\end{array}$} & \multicolumn{3}{|c|}{ Rotation Sums of Squared Loadings } \\
\hline & Total & $\begin{array}{l}\% \\
\text { Variance }\end{array}$ & $\begin{array}{l}\text { of Cumulative } \\
\%\end{array}$ & Total & $\begin{array}{l}\% \\
\text { Variance }\end{array}$ & $\begin{array}{l}\text { of Cumulative } \\
\%\end{array}$ & Total & $\begin{array}{l}\% \\
\text { Variance }\end{array}$ & $\begin{array}{l}\text { of Cumulative } \\
\%\end{array}$ \\
\hline 1 & 8.752 & 58.346 & 58.346 & 8.752 & 58.346 & 58.346 & 3.727 & 24.844 & 24.844 \\
\hline 2 & 1.101 & 7.339 & 65.684 & 1.101 & 7.339 & 65.684 & 3.616 & 24.104 & 48.948 \\
\hline 3 & 1.001 & 6.674 & 72.358 & 1.001 & 6.674 & 72.358 & 3.512 & 23.410 & 72.358 \\
\hline 4 & .696 & 4.639 & 76.998 & & & & & & \\
\hline 5 & .640 & 4.269 & 81.267 & & & & & & \\
\hline 6 & .578 & 3.852 & 85.119 & & & & & & \\
\hline 7 & .437 & 2.915 & 88.033 & & & & & & \\
\hline 8 & .396 & 2.640 & 90.673 & & & & & & \\
\hline 9 & .296 & 1.971 & 92.644 & & & & & & \\
\hline 10 & .267 & 1.780 & 94.424 & & & & & & \\
\hline 11 & .237 & 1.583 & 96.007 & & & & & & \\
\hline 12 & .197 & 1.311 & 97.317 & & & & & & \\
\hline 13 & .162 & 1.080 & 98.397 & & & & & & \\
\hline 14 & .129 & .858 & 99.255 & & & & & & \\
\hline 15 & .112 & .745 & 100.000 & & & & & & \\
\hline
\end{tabular}

Extraction Method: Principal Component Analysis

\section{Scree Plot}

Figure 1 presents the scree plot, which is taken by plotting the factors along $\mathrm{X}$-axis toward their eigenvalues along Y-axis. The aforementioned plot reveals that solely three factors with eigenvalues above elbow bent. Therefore, particularly three factors occurred retained in this study. 


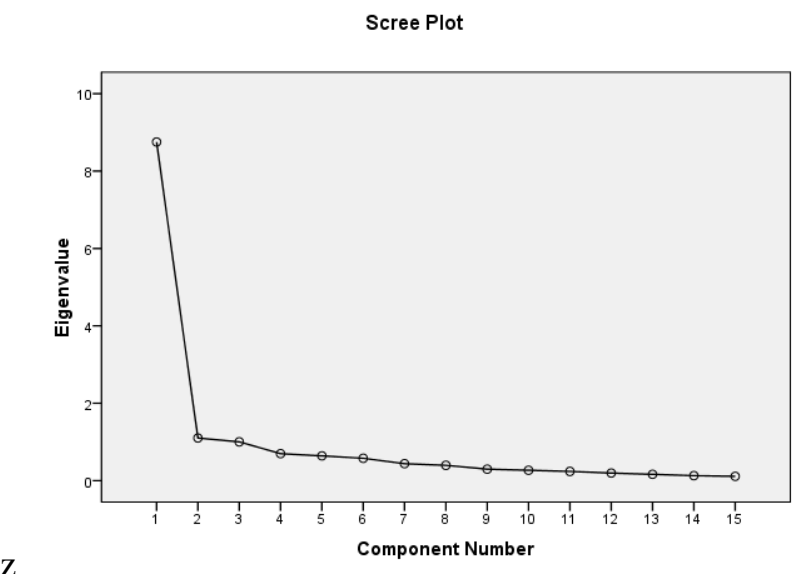

Figure 1. Scree Plot

\section{Extracted Factors}

Based on the statistical analysis, three factors are selected, and factor loadings of all the variables on each of the factors have been shown in table 6. Considering this is an unrotated factor solution, and some of the variables may show their contribution in more than one factor. To avoid this state, the factors are rotated and according to(Verma 2013)the varimax rotation has been used in this case to rotate the factors, as this is the most favoured approach used by the researchers due to its efficiency.

Variables are normally classified in a factor if their loading on factor 0.7 or more.(Verma 2013). This warrants that the factor obtains an adequate variance from that variable. However, one may lessen this threshold value if adequate variables cannot be distinguished in the factor. In this problem, the variables have been retained in a factor which its loadings are greater than or equal to 0.6. Owing to this criterion, variables have been grouped in each of the three factors, and test battery for factors on student satisfaction on the academic course is given in table 6.

Table 6. Component Matrix

\begin{tabular}{llll}
\hline Variables & Component & \multicolumn{2}{l}{$\mathbf{3}$} \\
\cline { 2 - 4 } & $\mathbf{1}$ & $\mathbf{2}$ & .305 \\
University is known nationally & .815 & .395 \\
University has maximum service & .761 & .711 & .581 \\
University has a good reputation in terms of direct graduates to work & .659 & .625 & .501 \\
University gives a classy impression when studying & .586 & .547 \\
The quality of university education is in accordance with government standards & & .847 \\
I chose the university because the quality of service matched my expectations & .458 & .748 & .519 \\
University provides health insurance for students who study & .351 & .668 \\
University provides convenience from the registration process to college & .322 & .663 \\
I feel happy to gain knowledge while studying at the university & .327 & .653 \\
I am happy to share university information with friends and family & & .501 \\
I feel proud studying at the university & & .430 \\
University provides scientific education and spiritual education & .338 & .792 \\
I chose the university because of my spiritual need & & .726 \\
I collected information before studying at the university & & .653 \\
I invite friends and family to study at the university & & .594 \\
\hline
\end{tabular}

Extraction Method: Principal Component Analysis.

Tabe 7.Test Battery

\begin{tabular}{lll}
\hline Variables & Loadings & Factors \\
\hline X3 & .815 & University is known nationally \\
X2 & .761 & University has maximum service \\
X1 & .711 & University has a good reputation in terms of direct graduates to work \\
X7 & .847 & University provides health insurance for students who study \\
X6 & .748 & University provides convenience from the registration process to college \\
X4 & .792 & University provides scientific education and spiritual education \\
X11 & .726 & I chose the university because of my spiritual need \\
\hline
\end{tabular}




\section{Test Battery}

The results in table 7 shows that factors in the analysis of student satisfaction on brand image and positioning at Asia-Pacific International University, Universitas Advent Indonesia and Adventist University of the Philippines. The following are factors regarding satisfaction in terms of brand image and positioning known nationally, maximum service, good reputation, provide health insurance, convenience registration process, and provide scientific education \& spiritual education, spiritual need.

\section{Conclusions and Recommendations}

Students as a customer give their initial perception based on the brand image and brand positioning of the higher education institution. Therefore, continuous monitoring of their satisfaction is deemed important, as it supports the growth and development of the institution. This is one reason that higher education institution should be given the essential facts and real measures in their assessment of the university brand. In order to generate a test battery to incorporate student satisfaction on academic courses, people can prefer variablesamong the distinguishing factors. Considering percentage contribution of every factor the in the extent of the total variability is the same, therefore one variable among every factor holding distinguished loadings on the factor may be picked up to generate the test battery for estimating the Student satisfaction on brand image and brand positioning. Thus, the test battery acquired is shown in the result section above such as known nationally, maximum service, good reputation, provide health insurance, convenience registration process, provide scientific education \& spiritual education, spiritual need. School management may determine more than one variable from one or two factors also, depending on their explainability. Scholars recommend working the confirmatory factor analysis with further data set to these questions before using this tool to estimate the student satisfaction on brand image and brand positioning because this meant a simulated study.

\section{References}

Athanassopoulos, Antreas, Spiros Gounaris, and Vlassis Stathakopoulos. 2001. "Behavioural Responses to Customer Satisfaction: An Empirical Study.” European Journal of Marketing. doi: 10.1108/03090560110388169.

Chua, Clare. 2004. "Perception of Quality in Higher Education." Proceedings of the Australian Universities Quality Forum 2004.

DeShields, Oscar W., Ali Kara, and Erdener Kaynak. 2005. "Determinants of Business Student Satisfaction and Retention in Higher Education: Applying Herzberg's Two-Factor Theory.” International Journal of Educational Management. doi: $10.1108 / 09513540510582426$.

Direkvand-Moghadam, A., Ataollah Hashemian, A. Delpisheh, F. Sohili, and K. Sayehmiri. 2014. "Effective Factors on Patients' Satisfaction with Emergency Care Services Using Factor Analysis: A Cross Sectional Study.” Journal of Clinical and Diagnostic Research. doi: 10.7860/JCDR/2014/8236.5162.

Ford, John B., Mathew Joseph, and Beatriz Joseph. 1999. "Importance-Performance Analysis as a Strategic Tool for Service Marketers: The Case of Service Quality Perceptions of Business Students in New Zealand and the USA." Journal of Services Marketing. doi: 10.1108/08876049910266068.

Helgesen, Øyvind, and Erik Nesset. 2007. "What Accounts for Students' Loyalty? Some Field Study Evidence.” International Journal of Educational Management.

James, Richard. 2002. "Students' Changing Expectations of Higher Education and the Consequences of Mismatches with Reality." Responding to Student Expectations.

Khosravi, Ali Akbar, Kambiz Poushaneh, Amitida Roozegar, and Nasrin Sohrabifard. 2013. "Determination of Factors Affecting Student Satisfaction of Islamic Azad University." Procedia - Social and Behavioral Sciences. doi: 10.1016/j.sbspro.2013.06.607.

Kuo, Yu Chun, Andrew E. Walker, Kerstin E. E. Schroder, and Brian R. Belland. 2014. "Interaction, Internet Self-Efficacy, and Self-Regulated Learning as Predictors of Student Satisfaction in Online Education Courses." Internet and Higher Education. doi: 10.1016/j.iheduc.2013.10.001.

Parahoo, Sanjai K., Heather L. Harvey, and Rana M. Tamim. 2013. "Factors Influencing Student Satisfaction in Universities in the Gulf Region: Does Gender of Students Matter?" Journal of Marketing for Higher Education.

Parasuraman, A., Leonard L. Berry, and Valarie A. Zeithaml. 1991. "Perceived Service Quality as a Customer-based Performance Measure: An Empirical Examination of Organizational Barriers Using an Extended Service Quality Model." Human Resource Management. doi: 10.1002/hrm.3930300304.

Priyatno, Duwi. 2014. SPSS 22 Pengola Data Terpraktis.

Shirazi, M. 2017. "Student Satisfaction Analysis and Its Factors (2014 to 2016)." Education.

Tahar, Nor Fadilah, Rashidah Mokhtar, Nur Huda Jaafar, Nur Diana Zamani, Safura Adeela Sukiman, and Zuriati Ismail. 2013. "Students' Satisfaction on Blended Learning: The Use of Factor Analysis." in 2013 IEEE Conference on e-Learning, e-Management and e-Services, IC3e 2013.

Umbach, Paul D., and Stephen R. Porter. 2002. "How Do Academic Departments Impact Student Satisfaction? Understanding the Contextual Effects of Departments." Research in Higher Education. doi: 10.1023/A:1014471708162.

Verma, J. P. 2013. Data Analysis in Management with SPSS Software.

Yusoff, Mazirah, Fraser McLeay, and Helen Woodruffe-Burton. 2015. "Dimensions Driving Business Student Satisfaction in Higher Education.” Quality Assurance in Education. doi: 10.1108/QAE-08-2013-0035. 